\title{
Establishment of research-oriented hospital: an important way for translational medicine development in China
}

\author{
MEINA LI and LULU ZHANG \\ Institute of Military Health Management, CPLA, Faculty of Health Service, The Second Military \\ Medical University, 800, Xiangyin Road, Yangpu District, 200433 Shanghai, China
}

Manuscript received on November 19, 2013; accepted for publication on June 23, 2014

\begin{abstract}
Globally, one of the major trends is the development of translational medicine. The traditional hospital structure could not meet the demands of translational medicine development any longer and to explore a novel hospital structure is imperative. Following the times, China proposed and implemented a development strategy for a first-class modern research-oriented hospital. To establish a research-oriented hospital has become an important strategy to guide the scientific development of high-quality medical institutions and to advance translational medicine development. To facilitate translational medicine by developing research-oriented hospital, the Chinese Research Hospital Association (CRHA) has been established, which provides service of medicine, talents cultivation, scientific research and clinical teaching and covers areas of theoretical research, academic exchange, translational medicine, talents training and practice guiding. On the whole, research-oriented hospital facilitated translational medicine by developing interdisciplinary platform, training core competencies in clinical and translational research, providing financial support of translational research, and hosting journals on translational medicine, etc.
\end{abstract}

Key words: translational medicine, clinical and translational research, management, collaboration, research hospital.

\section{INTRODUCTION}

Health, the predominant concern in society (Barata et al. 2014), calls for quick and effective medical applications of basic biomedical findings to benefit the patient, thus there is an increasing need for the integration of clinical research and biomedical research. Traditionally, clinical medicine focuses on patients, while medical science research institutions only focus on animal or cell. The way to connect these two is by developing translational medicine, which begins from the clinical problems and then

Correspondence to: Lulu Zhang

E-mail: zllrmit@aliyun.com goes to the clinical bench (Nussenblatt et al. 2010). Translational medicine orientates from clinical practices, achieves two-way conversion between the clinical practice and laboratory findings, promotes multi-disciplinarity, cross-disciplinary cooperation and involves the collaboration and knowledge management among different disciplines (Szalma et al. 2010, Littman and Marincola 2011) as well as the reorganization of medical resources in a translational way (Keramaris et al. 2008, Krontiris and Rubenson 2008). As a new major trend in the world, translational medicine calls for a novel institution different 
from scientific research institutions and traditional hospitals, namely, translational medicine center or translational research organizations (TROs) (Feldman et al. 2010). Translational research organizations (TROs), which gained high priority in some countries, seek to enhance the clinical impact of scientific discoveries and therefore play a multifaceted role. TROs are characterized by multidisciplinary collaboration, outreach initiatives, and the provision of shared resources and facilities (Pozen and Kline 2011). National Center for Advancing Translational Sciences (NCATS) has created Clinical and Translational Science Award (CTSA) sites creating a virtual national laboratory to collectively improve clinical and translational science in USA (Keramaris et al. 2008, Krontiris and Rubenson 2008). Currently, approximately 62 medical research institutions in 30 states and the District of Columbia are active members of the CTSA Consortium. Most translational medicine centers are led by universities. In Britain, the National Institute for Health Research (NIHR) has established 12 Biomedical Research Centers (BRCs) (Snape et al. 2008). In Germany, medical colleges and hospitals are subsidized to establish the integrated research and treatment center. The European Commission established the European Advanced Translational Research Infrastructure in Medicine (EATRIS) (Becker and van Dongen 2011) with members including many European translational medicine centers, such as the European Organization for Research and Treatment of Cancer (EORTC) (Psyrri et al. 2010). Brazil financial assisted National Science and Technology Institute for Translational Medicine (INCT-TM) to advance in the field of translational medicine (Hallak et al. 2010).

Translational medical research started late in China, but developed rapidly. Currently, dozens of translational medicine centers of different sizes have been established, most of which were organized spontaneously by local governments, universities or hospitals, including the Chinese Academy of Medical Sciences (CAMS), Peking Union Medical College (PUMC), the International Park of Translational Medicine and BioMedicine (IPTBM) (Wu et al. 2013). Translational medicine centers help spread the concept of translational medicine, and China plans to establish two national translational medicine research centers in Beijing and Shanghai located at the Peking Union Medical College and the Shanghai Jiaotong University. However, such a broad range of discipline coverage in translational medicine could not be achieved merely on one or two national translational medicine research centers or dozens of translational medicine centers, and more effort should be devote to translational medicine. Different from CTSA-funded translational medicine centers in the United States which mainly depend on the university, translational medicine centers in China were mostly grounded on hospitals, and account for $40 \%$. Translational medicine centers played a central and leading role and established the research networks and system based on research-oriented hospitals in China.

Research-oriented hospitals integrate the functions of traditional hospitals and research institution, and both provide medical service and undertake medical research, serving as the major platform for the development of translational medicine. The $13^{\text {th }}$ Special Session of Xiangshan Science Conference on December 2010 focused on translational medicine concerning accelerating changes of china's medical model and indicated that establishing research-oriented hospitals is an important way to solve the problem of medical conversion. In 2011, 10 ministries including the Ministry of Science, National Health and Family Planning Commission jointly developed the "Medical science and technology development plan (2011-2015)" and placed the construction of research-oriented hospitals into the middle and long term development blueprint for national science and technology. Through these measures, 
translational research in research-oriented hospital developed rapidly. Research-oriented hospital are characterized as follows (Qin et al. 2007): First, they can not only deal with the common and frequently encountered diseases, but also integrate multi-disciplinary advantages to cope with the difficult and complicated diseases and operations; Second, they develop new diagnostic and treatment technologies and methods through self-innovation and perform scientific research focusing on clinical problems and translate basic scientific findings to clinical practice; Third, they are the birth place of high-level talents; Fourth, they are the leading force in modern hospital reform and play a pivotal role in advancing a series of significant medical reforms involving disease prevention, medical service, and system organization; Fifth, they should establish the scientific criteria and guidelines of medical service. They should propose and implement new knowledge and idea, set up and spread the new diagnostic standards of diseases and provide references and guidelines in the medical field. With regard to translational medicine, researchoriented hospitals possess advantages as follows: research-oriented hospitals have an advantage over traditional hospitals in funds investment, technology and working experience of scientific research. Compared with the research institution, researchoriented hospitals directly serve the patient, understand the needs of the patient as well as the problems in diagnosis and treatment, thus have a more accurate and clear target for scientific research. Research-oriented hospitals tightly combine the clinical with the scientific research, compensating the weak points of each other. Besides, with highlevel talents, advanced technology and equipment and large number of patients, research-oriented hospitals act as an ideal place for the development of translational medicine. Namely, through research and innovation, they promote the conversion of scientific achievements, revolved around the need of human health and clinical service, consistently conquer clinical problems and improve clinical diagnosis and treatment, especially in some frontier areas such as regenerative medicine, molecular biology, stem cells and nano-medicine.

To facilitate translational medicine by developing research-oriented hospital, the Chinese Research Hospital Association (CRHA) was founded in Beijing on $21^{\text {st }}$ April 2013, and provides service of medicine, talents cultivation, scientific research and clinical teaching and covers areas of theoretical research, academic exchange, translational medicine, training and education. It proposed that medical development should switch to health promotion, organization mode to collaborative research, medical services to integration and industrial development to independent innovation. Over 120 presidents of leading hospitals in China joined in the CRHA. Different from NCATS and EATRs, CRHA aims to establish research-oriented hospitals to promote the development of translational medicine, thereby increasing the general level of medical care. The CRHA is dedicated to helping hospitals establish the new "clinical problem-laboratory and clinical research-clinical treatment" translational research system. That is, researchers begin from the clinical demands, turn the encountered clinical difficulties and challenges encountered into scientific issues, carry out basic research, apply and verify the results in clinical trail to derive new questions and start a new round of basic research. Therefore, a new mode was explored with regard to scientific and technological innovation which integrates medicine with pharmacy, medicine with industry, medicine with basic science, research with achievements transformation and promote research-oriented hospitals to become diagnosis and treatment bases for complicated and serious diseases, high-tech R \& D bases for advanced drugs and equipment, innovation bases for medical technologies and information exchange bases. The research-oriented hospital will become a base to implement the 
translational medicine, complete the mechanism and mode of translational medicine and strengthen the linkage and mutual promotion between medical science and technology and health needs.

In order to meet the development needs of translational medicine, interdisciplinary research platform which integrate medicine, biology, physics, materials and computer is needed. Platform for translational medicine could intensify the communication and coordination between hospitals and governments, enterprises, colleges and scientific research institutions, and integrate government policy, medical technology and industrial investment together. Platform for translational medicine could also optimize and integrate social resources, and gather translational medicine teams and experts and conduct international contact including communication, management consultation, theory study, talents cultivation, technology spread, achievements conversion and international cooperation. The CRHA will provide financial support to set up the collaboration and translational centers that cover multiple disciplines to promote the development of translational medicine in China. Research-oriented hospitals strives to support association between hospitals so that they can take advantage of each other' s strengths, share risks and benefits, and realize win-win results.

Taking the shortage of translational researchers into account, training and education toward translational medicine is of vital importance. CTSAfunded translational medicine centers in USA offer multiple training and education programs including degree program, certificate program, and courses for researchers, mentors and mentees to support interdisciplinary research leaders of the future. Harvard University provided MD-PhD, MD-MPH, MS-MBA, and MD-MPP program to develop multi-discipline researchers. China already attach importance to translational medicine education and training. Research-oriented hospital encouraged exchanges between existing medical doctors and scientists, and played an important role in talents cultivation in translational medicine. Researchoriented hospital focus on enhancing general innovation abilities, optimize and reorganize human resources and organize research teams with an appropriate combination of basic science researchers, clinical practitioners and achievements conversion experts as well as the high-level leading experts, young talents and scientific research assistants. At the same time, research-oriented hospital strive to create a favoring environment for conversion talents cultivation, focus on the crossdisciplinary thinking and coordinating abilities, instill translational medicine ideal into medical education and establish a joint mechanism between hospitals and universities for post-graduate cultivation. By constructing multidisciplinary academic committee and advisory committee, carrying out multilayer academic communication with universities and enterprises, offering variety courses including informatics, biostatistics, epidemiology, drug discovery, and ethics, personnel in research-oriented hospital were educated and trained through a combination approach of medicine, science and engineering to perform multidisciplinary research. After receiving special training, more and more personnel in hospital are able to handle both basic science research and clinical practice, which are rarely seen in the past.

Translational research cannot go without sufficient funds owing to its feature of high cost, long period and high failure rates. In the USA, the main financial support of translational research is NCATS which get more than $\$ 600$ million with respect to translational sciences in 2014. Similarly, most of funding programs of translational medicine come from government in China, including National natural science foundation and local government natural science foundation, foundation from municipal commission of Health and Family Planning, municipal Science and Technology Committee, etc. Guideline of Division of Medical Science of National Natural Science Foundation of 
China (2011) put forward to encourage translational medicine research which combines basic medicine and clinical practice together. Besides these major foundations, many research-oriented hospitals also set up foundations from part of their medical profits to support translational research, and give priority to programs which have the prospective of translating into clinical practice, thus get many internationally influential achievements.

Journals focusing on translational medicine have a critical impact on optimizing human health. China already have three newly published translational medicine journals "Translational Medicine Journal" (sponsored by Navy General Hospital), "Translational Medicine Research (Electronic Edition)" and "Translational Medicine and Scientific Research Management", the CRHA will host another journal entitled "Journal of China Research-oriented Hospital and Translational Medicine" (both in Chinese and English) to display the new domestic and international results in translational medicine and guide the construction of research-oriented hospitals and development of translational medicine.

Generally, translational medicine centers in China mainly depend on hospitals and researchoriented hospitals become the major institutions to develop translational medicine. Researchoriented hospitals will boost the development of translational medicine in talents cultivation, platform construction, management consultation, theory study and discussion, technology spread, achievements conversion and international cooperation, playing a pivotal role in intensifying connection and interaction between medical science and technology and health needs. Evaluation of translational medicine in research-oriented hospital can not merely get from quantity and quality of articles published, but also by patent granted and economical profit from patent, new drug or instrument developed, clinical standard establishment, public policy-making, and most importantly the improvement of medical service level.

\section{ACKNOWLEDGMENTS}

The project was supported by National Natural Science Foundation of China (71233008, 71303248), and Young Scientist Foundation of The Second Military Medical University (2012QN09).

\section{RESUMO}

Uma das tendências contemporâneas globais é o desenvolvimento da chamada medicina "transacional". A estrutura tradicional de hospitais não atende às demandas implicadas no desenvolvimento desta nova forma de investigação; explorar novas estruturas hospitalares torna-se imperativo. Atento às demandas atuais, o governo chinês propôs e implementou uma estratégia para a implantação de hospitais de primeiraclasse, orientados para a pesquisa moderna em Medicina. A implantação de unidades assistenciais com características de hospitais orientados para a pesquisa médica de fato mostrou-se uma estratégia importante para orientar o desenvolvimento científico de instituições de alta qualidade e para fomentar o desenvolvimento da investigação transacional. Para catalisar estas ações, criouse a Associação Chinesa de Hospitais de Pesquisa, que provê assistência médica, estimula o desenvolvimento de jovens talentos, desenvolve pesquisa médico-científica e atua na formação médica, cobrindo áreas de pesquisa teórica e prática, intercâmbios acadêmicos e formação de recursos humanos. De maneira geral, hospitais acadêmicos, orientados à pesquisa facilitam a tradução dos conhecimentos entre as diversas áreas da Medicina, estimulando a criação de plataformas interdisciplinares, treinando competências essenciais em pesquisa clínica e translacional, provendo suporte para a geração de conhecimento e sua difusão por meios acadêmicos.

Palavras-chave: medicina translacional, pesquisa clínica e transacional, gestão, colaboração, hospital de pesquisa/ hospital acadêmico.

\section{REFERENCES}

BARATA RB, ARAgão E, FERnANDES DE SOUSA LEP, SANTANA TM AND BARRETO ML. 2014. The configuration of the Brazilian scientific field. An Acad Bras Cienc 86: 505-521. 
BECKER R AND VAN DONGEN GAMS. 2011. EATRIS, a Vision for Translational Research in Europe. J Cardiovasc Transl Res 4: 231-237.

FELdMan AM, Force TL, Whellan DJ, BRAY PF, CheUnG JY AND KOCH WJ. 2010. Advancing the Research Mission in an Academic Department: The Creation of a Center for Translational Medicine. Cts Clin Transl Sci 3: 178-181.

Hallak JEC, CRIPPA JAS, QUEVEdo J, RoESler R, SCHROEDER N, NARDI AE AND KAPUINSKI F. 2010. National Science and Technology Institute for Translational Medicine (INCT-TM): advancing the field of translational medicine and mental health. Rev Bras Psiquiatr 32: 83-90.

Keramaris NC, KanAKARIS NC, Tzioupis C, Kontakis G AND GIANNOUDIS PV. 2008. Translational research: From benchside to bedside. Injury 39: 643-650.

KRONTIRIS TG AND RUBENSON D. 2008. Matchmaking, metrics and money: a pathway to progress in translational research. Bioessays 30: 1025-1029.

LITTMAN BH AND MARINCOLA FM. 2011. Create a translational medicine knowledge repository - Research downsizing, mergers and increased outsourcing have reduced the depth of in-house translational medicine expertise and institutional memory at many pharmaceutical and biotech companies: how will they avoid relearning old lessons? J Transl Med 9.
Nussenblatt RB, MARINCOLA FM AND SCHECHTER AN. 2010. Translational Medicine - doing it backwards. J Transl Med 8.

Pozen Rand KLINE H. 2011. Defining Success for Translational Research Organizations. Sci Transl Med 3.

PSYRri A, Licitra L, LACOMBE D, SCHUURING E, BUdACH W, OZSAHIN M, KNECHT R, VERMORKEN JB AND LANGENDIJK JA. 2010. Strategies to promote translational research within the European Organisation for Research and Treatment of Cancer (EORTC) Head and Neck Cancer Group: a report from the Translational Research Subcommittee. Ann Oncol 21: 1952-1960.

QIN Y, WEN D AND GUO X. 2007. Developing research hospital - management and practice of " 301 " hospital, Beijing: People's medical publishing house.

SNAPE K, TREMBATH RC AND LORD GM. 2008. Translational medicine and the NIHR Biomedical Research Centre concept. Qjm Int J Med 101: 901-906.

Szalma S, KoKa V, Khasanova T AND PERAKSLIS ED. 2010. Effective knowledge management in translational medicine. J Transl Med 8.

Wu X, Marincola FM, LIEBMan MN and Wang X. 2013. A global resource to translational medicine: the International Park of Translational Medicine and BioMedicine (IPTBM). J Transl Med 11. 